\title{
Institutional barriers to work beyond retirement in an aging Japan: Evidence from a recent employee survey
}

\author{
ATSUHIRO YAMADA and MASA HIGO
}

\begin{abstract}
This paper focuses on institutional barriers to older workers' continued work beyond the conventional retirement age in contemporary Japan. Under the current institutional arrangements, most older workers in Japan, contending with mandatory retirement rules at the workplace, have the option of being re-employed after mandatory retirement, and experience large wage reductions if they choose this option. We examine how these institutional arrangements in Japan today affect older workers' views and decisions regarding their future labor market behaviors. Using a multi-nomial logit analysis, we analyze data drawn from a nationally representative sample of 1,400 male regular employees, aged 57 to 59, who participated in the 2007 "Survey on continued employment and occupational life after age 60 (Rokujūsai ikō no keizoku kōyō to shokugyō seikatsu ni kansuru chōsa)", which was conducted by the Japan Institute for Labour Policy and Training (JILPT). Our analysis has found (i) that older workers do not want to be re-employed if their prospective wages are lower than their desired minimum level; (ii) that, if they choose not to be re-employed, they tend to seek alternative employment opportunities by themselves rather than retiring; and (iii) that, other than prospective wage level, the prospective total income (including "inwork" social security benefits) and the availability of flexible work arrangements are crucial factors affecting the future labor market behaviors of older workers.
\end{abstract}

Keywords: retirement; retirement policies; compensation packages; payment methods; the Law for the Stabilization of Employment of Older Persons (Kōnenreisha koyō antei-hō); re-employment. 


\section{日本における定年以降の就業に対する制度的障害 : 最新の被用者データに基づく証拠}

本稿では、今日の日本において、高齢者が一般的な定年年齢を超えて 継続就業する際の制度的障害について焦点をあてる。現行の日本の一 般的な雇用慣行では、定年退職慣行がある場合、多くの高齢就業者は 同一企業で再雇用され、この再雇用により大幅な貨金低下を経験する ことになる。こうした制度設計が、今日の日本における定年到達前の 高齢者の将来の就業行動に対する考え方、将来の就業意思決定によ゙の ような影響を及ぼすか検討する。JILPTが日本全国の高齢者にたいし て実施した『60歳以降の継続雇用と就業選択に関する調査』個票デー タから、57〜 59歳男性サンプルを用い、多肢選択ロジット・モデルで 分析した。その結果、（i）再雇用後に最低限期待する賃金を予想賃金 が下回ると同一企業での再雇用を希望しなくなること、（i i ）ただし、 再雇用を希望しなくても引退するのではなく職探しをすること、(i i i ) 再雇用後の予想貨金以外にも、在職老齢年金等を含む再雇用後の予想 総所得、柔軟な働き方などが再雇用後の高齢者の就業選択に大きな影 響を与える要因であることを明らかにした。

\section{Introduction}

The aging of the population and of the workforce projected for the decade ahead has pressured most industrialized countries to delay retirement for older workers. If substantially more workers were to remain in the labor force longer than they currently do, it would help increase the sustainability of existing social security programs, including public pension and healthcare schemes (Munnell and Sass 2008). In this context, over roughly the last decade, policymakers in many industrialized countries have been concerned with institutional barriers in the labor market that inhibit the desired delay in the retirement of older workers, while researchers around the world have begun to study institutional factors in the labor market that constrain opportunities and reduce motives for continued employment of older workers beyond the conventional retirement age (Schulz and Binstock 2008).

Among the industrial and aging nations around the world, Japan has experienced the fastest population aging over the past few decades and, as a consequence, anticipates a severe workforce shortage in the coming decades (OECD 2004). Against this backdrop, in this paper we focus on the institutional arrangements of mandatory retirement in Japan. This paper pays special attention to the severely reduced wages for work available after mandatory retirement from career jobs. 
Today, a substantial portion of older regular employees in private sector workplaces - that is, people who are employed in business firms on a full-time and permanent contractual basis - experience dramatic wage reductions when they continue working in some capacity after mandatory retirement. To date, in the Japanese labor market, there is no legislation equivalent to the Age Discrimination in Employment Act of 1967 in the United States. ${ }^{1}$ Partly reflecting the absence of such an anti-age discrimination law, mandatory retirement is still a prevalent employer practice in most workplaces in Japan (Higo and Yamada 2009). Today, almost all Japanese companies and firms with more than 100 employees have implemented mandatory retirement corporate policies and, as of 2009 , about $90 \%$ of them set 60 as the mandatory retirement age (MHLW 2009).

The current institutional arrangements in Japan provide a substantial portion of older workers who are corporate employees with the option of continuing to work for the same employers after reaching mandatory retirement age (MHLW 2010). In this context, employers typically terminate their workers' long-term employment once they reach the conventional mandatory retirement age and then re-employ them in a different or modified capacity but within the same firm (MHLW 2009). For most older workers and employees this typical institutional arrangement means that they experience large wage reductions if they choose to be re-employed. And much to the concern of policymakers, there are only few employment opportunities available in the labor market for older workers who have retired due to mandatory retirement (Yamada 2010).

In this paper, we ask in what ways the institutional arrangements of large wage reductions in today's Japanese labor market shape the decisions of older workers concerning their future labor market behaviors, including whether they decide to retire or continue to work beyond the mandatory retirement age (typically, age 60). To address this topic, this paper aims to answer the following three research questions:

- Does the institutionally arranged large wage reduction actually discourage older workers from choosing to be re-employed by the same employers after mandatory retirement?

- If choosing not to be re-employed, what labor market options do older workers envision taking?

- Other than the large wage reduction, what other institutional factors discourage older workers from choosing to be re-employed by their employers?

The goals of this paper are two-fold: First, we aim to contribute to a growing body of knowledge concerning the ways in which the current 
labor market institutions in Japan shape older workers' retirement decisions and their future prospects in the labor market. Second, based on findings, we aim to draw sources for policy suggestions for those who seek ways to mitigate labor market institutional barriers to older workers' continued employment beyond conventional retirement age.

Toward the first goal, we examine the factors that affect older workers' decision making with respect to re-employment by their employers, their searching for alternative employment opportunities outside the re-employment arrangements, and their withdrawal from the labor force (retirement). And by focusing on the case of contemporary Japan, we aim to facilitate an understanding of international variations on this subject.

In cross-national comparative literature, roughly since the late 1990s, old-age pension schemes have been extensively discussed as one of the most powerful institutional factors affecting older people's labor market behaviors (see Blöndel and Scarpetta 1998; Duval 2003; Gruber and Wise 1999, 2004; Schils 2005). Much empirical research suggests that the structure of old-age pension schemes influences older people's labor market behaviors and that, when designed generously, old-age pension schemes contribute to significantly reducing older people's labor force participation. Other institutional factors in the labor market, such as steep wage curves and strict employment protection legislation, also contribute to encouraging early retirement among older workers (OECD 2006).

In this regard, Japan is not an exception - much research focusing on the case of Japan has suggested that the earnings-test components of the current pension scheme contribute to discouraging older workers' labor force participation. ${ }^{2}$ Furthermore, to date, most research on this subject has focused on the outcome of older workers' labor market behaviors as a crude indicator to assess the decisions made by these workers and employees. Therefore, past research has not sufficiently examined older workers' own perspectives on how the current institutional arrangements might shape their choices. We also argue that, to date, little research has closely examined the potential discrepancies between the workers" "desired" (ideal) and "anticipated" (realistic) work arrangements in their re-employment after mandatory retirement.

To help fill this gap, we specifically examine factors which affect older workers' decision making with respect to their potential re-employment by their employers. We also examine factors affecting their search for alternative employment opportunities outside the re-employment arrangements and their withdrawal from the labor force. Part of our research question also aims to address the ways in which the 
discrepancies affect older workers' own perspectives on their future labor market participation prospects.

Toward the second goal, this paper aims to draw policy implications for those who seek ways to mitigate labor market institutional barriers to older workers' continued employment beyond the conventional retirement age. Policy implications in this paper include suggesting the potential importance of introducing to the labor market in Japan antiage discrimination legislation aiming to prohibit large wage reductions for older workers who have passed conventional retirement age.

\section{The background}

Older workers in Japan - particularly regular employees in private sector workplaces - tend to experience large wage reductions if they choose to be re-employed by the same employers after mandatory retirement. This particular institutional arrangement has been developed due largely to the government's intervention in the labor force in the context of the country's fast-paced aging of the population and of the workforce (JILPT 2009). With a variety of measures, the government has long intervened in the labor market in response to the anticipated increase of the fiscal burden of age-related social expenditures due to an expected severe workforce shortage in the coming decade.

Two directions that the government has taken to intervene into the country's aging workforce have made definitive contributions to institutionalizing this large wage reduction. The measures are the government's initiatives to gradually increase (i) the minimum eligibility age for part of the public pension benefits and (ii) the age criteria set by employers for their mandatory retirement corporate policies.

First, the Employees Pension (EP), which is part of the general public pension scheme, covers most regular employees in private sector workplaces in Japan today (OECD 2004). The EP scheme is designed to provide beneficiaries with both flat-rate and earnings-related pension benefits. ${ }^{3}$ Until 2000, the minimum eligibility age for full EP benefits, including both flat-rate and earnings-related portions, was set at age 60 - the age around which most employers have called for mandatory retirement to date (MHLW 2008).

Over the past few decades, this EP component of the public pension scheme has been subject to a series of reforms, aiming to improve its fiscal sustainability (JILPT 2009). ${ }^{4}$ Two types of upward revisions of the pensionable age in the EP scheme, which had been set at 60 and is being raised gradually at the rate of plus-one-year-of-age every three years, are important elements of these reforms. A 1994 pension reform introduced the plan for the upward revision of the pensionable age for 
the flat-rate portion of the EP scheme; the initial age raise (to age 61) took effect in 2001, and it is scheduled to reach a final age of 65 in 2013 (Cabinet Office 2010). In addition, a 2000 pension reform scheduled the upward revision of the pensionable age for the earnings-related portion of the EP scheme to take initial effect in 2013 and to be finalized in 2025 (OECD 2004). With these schedules, as of 2010, the pensionable age for the EP's flat-rate portion is 64 and the pensionable age for the earnings-related portion is 60 (Cabinet Office 2010).

In 1998 the government amended the Law for the Stabilization of Employment of Older Persons (Kōnenreisha koyō antei-hō; LSEOP, hereafter) in response to the upward revision of the pensionable age for the flat-rate portion of the EP scheme (Yamada 2007). The 1998 amendment of the LSEOP obliged employers to "make an effort" to ensure the job security of their employees up to age 65 . This amendment was expected to contribute to solving the blank period of income stream for older people between their mandatory retirement age and their full pensionable age. However, official statistics show that by 2004 , only $16 \%$ of firms with mandatory retirement schemes had implemented continuous employment beyond mandatory retirement age (MHLW 2006). This fact suggested that the law has been ineffective in securing employment opportunities of older workers who reach conventional mandatory retirement age. This also implies that there are risks associated with financial security among older people in the country, particularly among those aged 60 to 65 . In this context, the government has been spurred to strengthen the effectiveness of the law (JILPT 2009).

The latest amendment of the LSEOP, enacted in April 2006, mandates that employers implement at least one of three sets of job security measures for older workers in line with the upward revision of pensionable age (JILPT 2007). The three measures include: (i) the full abolition of mandatory retirement rules in the workplace; (ii) an increase in the minimum age for mandatory retirement to at least the pensionable age for the flat-rate portion of the public pension scheme (e.g., age 64 or older in 2010); and (iii) the re-employment of those employees who reach mandatory retirement age at least up to the pensionable age of the flat-rate portion of the EP scheme (Cabinet Office 2010).

As of today, most employers have chosen the last option, that of offering their older workers continued employment opportunities (JILPT 2007). Few employers have chosen the first and second options. Abolishing mandatory retirement rules would be challenging due primarily to older workers' high wages relative to what employers perceive as their actual productivity at work. The second option requires that employers continue to employ older workers without changing 
their employment status, job contents, and wages at least until age 65 . The third option, to provide continued employment through re-employment after mandatory retirement age, does not mandate that employers unconditionally guarantee the secure employment of older workers until the pensionable age of the EP's flat-rate portion. Rather, this option merely requests that employers introduce measures aiming to provide their older workers with opportunities to remain employed at least until age 65 . In effect, this option provides employers with a considerable degree of discretion in changing the terms of employment for those employees who choose to be re-employed in their workplaces after reaching the mandatory retirement age. Thus, employers may change those employees' wages, employment status, work schedule, job contents, and even workplace (through transfers within the employer's business networks) (Yamada 2007).

In today's labor market, therefore, the government has aimed to promote older workers' continued employment beyond the conventional mandatory retirement age of 60 mainly by mandating that employers gradually increase the age criteria set for mandatory retirement through the option of re-employment after mandatory retirement (Higo and Yamada 2009). Simultaneously, the government has clearly acknowledged the mounting pressure facing many employers, particularly large ones, to reduce human resource costs in order to maintain organizational vitality in the wake of a prolonged economic recession that the country has been experiencing since the early 1990s. Thus, the government affirms that, in exchange for retaining employees beyond age 60, employers may once terminate employment of those who have reached mandatory retirement age, re-employ them, and downgrade their status from regular employees to nonregular employees (e.g., temporary or part-time positions) with significantly reduced wages and benefits (Ono 2007).

Importantly, research suggests that these institutional arrangements surrounding older workers after mandatory retirement have generated an adverse effect. Employers may use the institutionally arranged large wage reduction for older workers as a human resource management tool to induce older workers to leave their employment "voluntarily" (Yamada 2007).

Nevertheless, it is noteworthy that a large wage drop upon re-employment is not necessarily an unusual phenomenon or exploitation. Literature on personnel economics offers several potentially useful theoretical accounts for why some workers experience large wage reductions after mandatory retirement in the labor market of an industrialized country. For instance, Lazear $(1979,1986)$ argues that wage profiles tend to have an upward slope, even if the value of the marginal 
productivity (VMP) of workers is constant; employers pay wages below the VMP when workers are young and pay wages above the VMP when workers are old. In his view, by shifting compensation to the end period of this type of implicit contract, workers are discouraged from shirking or engaging in malfeasance. Therefore, the wage drop after mandatory retirement can be partly explained by the termination of this sort of deferred wage contract (Lazear 1979, 1986).

\section{Data and methodology}

In this paper we analyze data drawn from a survey titled Rokujūsai ikō no keizoku kōyō to shokugyō seikatsu ni kansuru chōsa ('Survey on continued employment and occupational life after age 60'; SCOLA 2007 hereafter), ${ }^{5}$ which was conducted by the Japan Institute of Labor Policy and Training (JILPT hereafter) in February 2007. The SCOLA survey gathered data from a large nationally representative sample of which we draw on data collected from the responses of 1,400 male regular employees working in different parts of Japan. In collaboration with 5,000 randomly sampled private sector firms (each with 300 or more employees) across the country, JILPT distributed the SCOLA survey questionnaires only among regular employees aged 57 to 59 .

The SCOLA survey asked a number of questions concerning respondents' perspectives on their future labor market opportunities, prospects, and decisions. Some of the questions inquired about respondents' perspectives on their anticipated future decisions about taking up re-employment opportunities with the same employers after reaching the mandatory retirement age set by the employers. Respondents were also asked whether they thought that they would choose not to be re-employed but would seek employment opportunities outside the institutional arrangements for re-employment or fully retire from their working lives. The questionnaires were distributed as self-addressed return mails, and the response rate was about $5 \%$.

For our analysis, we focused on male regular employees in the category of older workers in private sector workplaces and selected data drawn from a sample of 1,400 men without missing variables. Excluded from our analysis are data drawn from female respondents, due mainly to a potential complexity associated with influences of joint retirement decisions on older female workers (see Hurd 1990). Employing basic tabulation and a multi-nominal logit model, the analysis included the following variables as predictors: education level, length of service, number of dependent family members, presence of any family member who needs long-term care, health status, experiences of job change and/ or employment transfer, firm size (number of employees), having or 
Table 1. Definitions of dummy variables for desired and anticipated future work conditions.

Work status Dummy variables for combinations of desired and anticipated employment status after mandatory retirement (age 60).

Type A Regular employment is both desired and anticipated (the base category for desired/anticipated work status types).

Type B Regular employment is desired, but nonregular employment is anticipated (i.e., contracted, part time, or dispatched worker).

Type C Nonregular employment is desired, and the anticipated type of nonregular employment is matched (e.g., the desired type is contracted employment, and the anticipated type is also contracted employment).

Type D Nonregular employment is desired, but the anticipated type of nonregular employment is mismatched (e.g., the desired type is contracted employment, but the anticipated type is part-time employment).

Type E Other combinations.

Work hours Dummy variables for combinations of desired and anticipated work hour in re-employment at the same firm.

Type A Full-time work is both desired and anticipated (the base category for desired/anticipated work hour types).

Type B Full-time work is desired, but shorter work hours are anticipated.

Type C Shorter-time work than full-time work is desired, and the anticipated work hour type is matched (i.e., shorter work days, shorter work hours, flextime, or telework).

Type D Shorter time than full-time work is desired, but the anticipated work hour type is mismatched.

Type E Other combinations.

Workplace Dummy variables for combinations of desired and anticipated work place in re-employment at the same firm.

Type A The same workplace, where employee is now working, is both desired and anticipated (i.e., both the establishment and the division are the same as the current one) (the base category for desired/anticipated workplace types).

Type B The same workplace is desired, but a different workplace is anticipated.

Type C A different workplace is both desired and anticipated.

Type D A different workplace is desired, but the same establishment or the same division is anticipated.

Type E Other combinations. 
Table 1. (continued)

Job contents Dummy variables for combinations of desired and anticipated job content in re-employment at the same firm.

Type A The same job content, which is the respondent's current duty, is both desired and anticipated (the base category for desired/anticipated job content types).

Type B The same job content is desired, but different job content is anticipated.

Type C A different job is desired, and this different job is anticipated.

Type D A different job is desired, but the same job is anticipated.

Type E Other combinations.

lacking corporate pension rights, anticipated wage reductions and desired/anticipated work conditions in re-employment in the same firm after mandatory retirement age, area of residence, house ownership, and location of workplace.

In order to examine discrepancies between respondents' desired (ideal) and anticipated (realistic) future work conditions, we considered four factors: employment status, work hours, work place, and job contents. On the basis of a combination of desired and anticipated work conditions in re-employment at the same firm, we created five dummy variables (Table 1) for each of the four factors.

For our analysis, we first hypothesize that the discrepancies between desired and anticipated work conditions affect male regular employees' decisions about (i) choosing to be re-employed (at the same firms), (ii) retiring from the labor force, and (iii) conducting a job search (seeking employment at other firms). We also hypothesize that discrepancies between desired and anticipated work conditions reduce the probability of re-employment in the same firms, and that the discrepancies would also simultaneously increase the probability of retirement or job search after mandatory retirement. From policymakers' perspectives, the increased probability of retirement would be a problem, as it is opposed to active aging policy and would cause fiscal pressure on the country's public pension schemes.

Table 2, which presents key statistics used in the analysis, indicates that the majority of the SCOLA survey respondents - male regular employees - would choose to be re-employed at the same firms after mandatory retirement. About $74 \%$ of respondents $-1,039$ out of the 1,400 respondents - reported that they desired to be re-employed at the same firms after mandatory retirement. About $10 \%$ of the respon- 
Table 2. Key variables from the 2007 survey on continued employment and occupational life after age 60 (own calculations based on SCOLA 2007).

\begin{tabular}{|c|c|c|c|c|c|c|}
\hline & \multicolumn{2}{|c|}{ Retirement } & \multicolumn{2}{|c|}{$\underline{\text { Re-employment }}$} & \multicolumn{2}{|c|}{ Job search } \\
\hline & Mean & SD & Mean & SD & Mean & $\mathrm{SD}$ \\
\hline With spouse & 0.918 & {$[0.2755]$} & 0.919 & {$[0.2727]$} & 0.934 & [0.2482] \\
\hline With dependent family member & 0.366 & {$[0.4834]$} & 0.459 & {$[0.4986]$} & 0.492 & {$[0.5013]$} \\
\hline With relatives needing long-term care & 0.231 & [0.4233] & 0.198 & [0.3989] & 0.290 & [0.4548] \\
\hline With health problem & 0.299 & {$[0.4593]$} & 0.124 & {$[0.3299]$} & 0.175 & [0.3809] \\
\hline With home ownership & 0.910 & {$[0.2866]$} & 0.905 & {$[0.2937]$} & 0.902 & {$[0.2986]$} \\
\hline Workplace located in Tokyo & 0.134 & {$[0.3423]$} & 0.230 & {$[0.4211]$} & 0.230 & {$[0.4217]$} \\
\hline $\begin{array}{l}\text { Education: junior high school } \\
\text { (the base category) }\end{array}$ & 0.097 & {$[0.2971]$} & 0.078 & {$[0.2682]$} & 0.071 & {$[0.2576]$} \\
\hline Education: high school & 0.433 & {$[0.4973]$} & 0.489 & {$[0.5001]$} & 0.426 & [0.4959] \\
\hline Education: two-year college & 0.075 & {$[0.2638]$} & 0.064 & {$[0.2440]$} & 0.055 & [0.2279] \\
\hline Education: four-year college & 0.396 & [0.4908] & 0.370 & [0.4829] & 0.448 & [0.4987] \\
\hline Length of service (years) & 30.470 & {$[11.753]$} & 29.440 & {$[12.397]$} & 28.973 & [12.322] \\
\hline $\begin{array}{l}\text { Anticipated income fall: } \\
\text { by less than } 20 \% \text { (the base category) }\end{array}$ & 0.067 & {$[0.2512]$} & 0.091 & {$[0.2884]$} & 0.022 & {$[0.147]$} \\
\hline Anticipated income fall: by $10-20 \%$ & 0.209 & {$[0.4081]$} & 0.166 & {$[0.3718]$} & 0.120 & {$[0.3261]$} \\
\hline Anticipated income fall: by $30-40 \%$ & 0.366 & {$[0.4834]$} & 0.380 & {$[0.4857]$} & 0.306 & {$[0.4621]$} \\
\hline Anticipated income fall: by $50-60 \%$ & 0.261 & {$[0.4409]$} & 0.304 & {$[0.4603]$} & 0.410 & {$[0.4932]$} \\
\hline Anticipated income fall: by $70 \%$ and more & 0.097 & {$[0.2971]$} & 0.059 & {$[0.2352]$} & 0.142 & {$[0.3501]$} \\
\hline $\begin{array}{l}\text { Anticipated wage drop: by less than } 20 \% \\
\text { (the base category) }\end{array}$ & 0.045 & {$[0.2076]$} & 0.056 & {$[0.2297]$} & 0.016 & [0.1273] \\
\hline Anticipated wage drop: by $10-20 \%$ & 0.097 & {$[0.2971]$} & 0.110 & 27] & 0.071 & [0.2576] \\
\hline Anticipated wage drop: by $30-40 \%$ & 0.425 & {$[0.4963]$} & 0.384 & {$[0.4866]$} & 0.295 & {$[0.4573]$} \\
\hline Anticipated wage drop: by $50-60 \%$ & 0.276 & {$[0.4488]$} & 0.349 & {$[0.4770]$} & 0.448 & [0.4987] \\
\hline Anticipated wage drop: by $70 \%$ and more & 0.157 & {$[0.3649]$} & 0.101 & {$[0.3016]$} & 0.169 & {$[0.3761]$} \\
\hline the base category) & 0.194 & {$[0.3969]$} & 0.232 & {$[0.4223]$} & 0.240 & [0.4285] \\
\hline Main career: managerial & 0.142 & {$[0.3501]$} & 0.115 & {$[0.3198]$} & 0.109 & [0.3129] \\
\hline Main career: professional & 0.045 & {$[0.2076]$} & 0.068 & {$[0.2524]$} & 0.027 & {$[0.1635]$} \\
\hline Main career: clerical & 0.075 & {$[0.2638]$} & 0.046 & {$[0.2100]$} & 0.049 & [0.2168] \\
\hline Main career: technical/skilled & 0.022 & {$[0.1485]$} & 0.023 & {$[0.1503]$} & 0.055 & [0.2279] \\
\hline Main career: sales workers & 0.299 & {$[0.4593]$} & 0.226 & {$[0.4186]$} & 0.240 & {$[0.4285]$} \\
\hline Main career: logistic workers & 0.060 & {$[0.2378]$} & 0.053 & {$[0.2240]$} & 0.055 & [0.2279] \\
\hline Main career: researchers and developers & 0.067 & {$[0.2512]$} & 0.089 & {$[0.2842]$} & 0.109 & [0.3129] \\
\hline Main career: other & 0.097 & {$[0.2971]$} & 0.147 & {$[0.3545]$} & 0.115 & [0.3196] \\
\hline $\begin{array}{l}\text { Firm size: less than } 300 \text { employees } \\
\text { (the base category) }\end{array}$ & 0.045 & {$[0.2076]$} & 0.052 & {$[0.2221]$} & 0.077 & [0.2665] \\
\hline Firm size: $300-499$ employees & 0.343 & {$[0.4766]$} & 0.326 & {$[0.4691]$} & 0.350 & [0.4782] \\
\hline Firm size: 500-999 employees & 0.276 & {$[0.4488]$} & 0.346 & {$[0.4761]$} & 0.284 & {$[0.4522]$} \\
\hline Firm size: 1000-2999 employees & 0.246 & {$[0.4325]$} & 0.199 & {$[0.3996]$} & 0.224 & {$[0.4181]$} \\
\hline Firm size: 3000 and more employees & 0.090 & {$[0.2866]$} & 0.076 & {$[0.2652]$} & 0.066 & [0.2482] \\
\hline Experience of job change & 0.403 & {$[0.4923]$} & 0.418 & {$[0.4934]$} & 0.443 & [0.4981] \\
\hline Experience of employment transfer & 0.119 & {$[0.3255]$} & 0.122 & {$[0.3277]$} & 0.115 & [0.3196] \\
\hline Work Status Type A (the base category) & 0.075 & {$[0.2638]$} & 0.108 & {$[0.3103]$} & 0.093 & [0.2911] \\
\hline Work Status Type B & 0.358 & {$[0.4813]$} & 0.546 & {$[0.4981]$} & 0.481 & [0.5010] \\
\hline Work Status Type C & 0.455 & [0.4999] & 0.299 & {$[0.4582]$} & 0.290 & [0.4548] \\
\hline Work Status Type D & 0.082 & {$[0.2755]$} & 0.027 & {$[0.1620]$} & 0.109 & [0.3129] \\
\hline Work Status Type E & 0.030 & {$[0.1708]$} & 0.020 & {$[0.1408]$} & 0.027 & {$[0.1635]$} \\
\hline
\end{tabular}


Table 2. (continued)

\begin{tabular}{|c|c|c|c|c|c|c|}
\hline & \multicolumn{2}{|c|}{$\underline{\text { Retirement }}$} & \multicolumn{2}{|c|}{$\underline{\text { Re-employment }}$} & \multicolumn{2}{|c|}{ Job search } \\
\hline & Mean & SD & Mean & SD & Mean & SD \\
\hline Work Hours Type A (the base category) & 0.284 & [0.4524] & 0.518 & [0.4999] & 0.393 & [0.4899] \\
\hline Work Hours Type B & 0.082 & [0.2755] & 0.101 & {$[0.3016]$} & 0.060 & {$[0.2383]$} \\
\hline Work Hours Type C & 0.172 & {$[0.3785]$} & 0.130 & {$[0.3364]$} & 0.093 & {$[0.2911]$} \\
\hline Work Hours Type D & 0.455 & {$[0.4999]$} & 0.230 & {$[0.4211]$} & 0.432 & {$[0.4967]$} \\
\hline Work Hours Type E & 0.007 & {$[0.0864]$} & 0.021 & {$[0.1440]$} & 0.022 & {$[0.1466]$} \\
\hline Workplace Type A (the base category) & 0.187 & [0.3910] & 0.381 & [0.4859] & 0.153 & {$[0.3610]$} \\
\hline Workplace Type B & 0.052 & {$[0.2233]$} & 0.056 & [0.2297] & 0.027 & {$[0.1635]$} \\
\hline Workplace Type C & 0.455 & [0.4999] & 0.317 & {$[0.4654]$} & 0.311 & {$[0.4644]$} \\
\hline Workplace Type D & 0.254 & [0.4368] & 0.192 & [0.3937] & 0.372 & {$[0.4846]$} \\
\hline Workplace Type E & 0.052 & {$[0.2233]$} & 0.055 & {$[0.2278]$} & 0.137 & {$[0.3444]$} \\
\hline Job Contents Type A (the base category) & 0.575 & [0.4963] & 0.714 & {$[0.4520]$} & 0.432 & [0.4967] \\
\hline Job Contents Type B & 0.149 & {$[0.3577]$} & 0.129 & {$[0.3353]$} & 0.104 & {$[0.3059]$} \\
\hline Job Contents Type C & 0.119 & {$[0.3255]$} & 0.070 & {$[0.2557]$} & 0.208 & {$[0.4067]$} \\
\hline Job Contents Type D & 0.119 & {$[0.3255]$} & 0.049 & {$[0.2162]$} & 0.197 & {$[0.3986]$} \\
\hline Job Contents Type E & 0.037 & {$[0.1902]$} & 0.038 & {$[0.1902]$} & 0.060 & {$[0.2383]$} \\
\hline No corporation pension right & 0.047 & {$[0.2122]$} & 0.069 & {$[0.2541]$} & 0.087 & {$[0.2832]$} \\
\hline$n$ & 134 & & 1039 & & 183 & \\
\hline
\end{tabular}

dents - 183 out of the 1,400 respondents - reported that after mandatory retirement they wanted to search for alternative employment opportunities outside their firms. It should be noted that these responses were provided based on the respondents' perceptions when they were between the ages of 57 and 59. Upon reaching mandatory retirement age (mostly age 60), they might actually choose different options.

\section{Results}

We started our analysis by examining discrepancies between "desired" and "anticipated" work conditions in re-employment using some basic tabulation. Table 2 presents a cross tabulation of desired minimum annual income by anticipated annual income in re-employment as a percentage of current annual income. The data presented in Table 3 are drawn from those males, age 57 to 59, who anticipate working for the same firms under re-employment arrangements after mandatory retirement. In this context, annual income refers to an aggregate of annual wages, bonus benefits, and social security benefits, including both public pensions and old workers' salary supplements.

Some discrepancies were revealed between desired minimum income and anticipated income after age 60 . For instance, about $35.8 \%$ of respondents reported that their desired minimum income level would be $60 \%$ to $70 \%$ of their current (pre-mandatory retirement) income level. 
Table 3. Desired minimum income versus anticipated income after age 60 (as a percentage of current income, male regular employees aged 57 to $59, \mathrm{~N}=1356$ ) (own calculations based on SCOLA 2007).

\begin{tabular}{|c|c|c|c|c|c|c|c|}
\hline \multirow{2}{*}{$\begin{array}{l}\text { Desired minimum } \\
\text { income }\end{array}$} & \multicolumn{7}{|c|}{ Anticipated income level } \\
\hline & $\begin{array}{l}\text { More } \\
\text { than the } \\
\text { current } \\
\text { level }\end{array}$ & Same & $\begin{array}{l}80- \\
90 \%\end{array}$ & $\begin{array}{l}60- \\
70 \%\end{array}$ & $\begin{array}{l}40- \\
50 \%\end{array}$ & $\begin{array}{l}\text { Less } \\
\text { than } \\
30 \%\end{array}$ & Total \\
\hline $\begin{array}{l}\text { More than the } \\
\text { current level }\end{array}$ & 0.1 & 0.2 & 0.4 & 0.1 & 0.0 & 0.0 & 0.8 \\
\hline Same & 0.5 & 2.9 & 6.4 & 6.6 & 3.0 & 0.3 & 19.7 \\
\hline $80-90 \%$ & 0.1 & 3.2 & 3.6 & 16.3 & 6.5 & 0.4 & 30.1 \\
\hline $60-70 \%$ & 0.0 & 0.8 & 5.0 & 9.7 & 17.0 & 3.2 & 35.8 \\
\hline $40-50 \%$ & 0.0 & 0.1 & 1.0 & 4.0 & 3.8 & 3.1 & 11.9 \\
\hline Less than $30 \%$ & 0.0 & 0.1 & 0.0 & 0.1 & 1,1 & 0.4 & 1.7 \\
\hline Total & 0.7 & 7.3 & 16.4 & 36.9 & 31.4 & 7.4 & 100.0 \\
\hline
\end{tabular}

Some $30.1 \%$ of respondents reported that their desired minimum income level would be $80 \%$ to $90 \%$ of their current income level. These two response categories comprise the largest portion of responses. By contrast, about $36.9 \%$ of respondents reported that their anticipated income level would be $60 \%$ to $70 \%$ of their current income level, and some $31.4 \%$ reported that their anticipated income level would be only $40 \%$ to $50 \%$ of their current level.

Concerning the comparison between desired and anticipated income levels after mandatory retirement, we observed some gaps; for instance, about $17.0 \%$ of respondents reported that they desired to receive at minimum $60 \%$ to $70 \%$ of their current income, but they reported that they anticipated receiving only $40 \%$ to $50 \%$ of current income. Additionally, some $16.3 \%$ of respondents reported that they desired to receive at least $80 \%$ to $90 \%$ of their current income after mandatory retirement, but they reported that they anticipated actually receiving about $60 \%$ to $70 \%$ of their current income level. Only about $9.6 \%$ of respondents reported matching desired and anticipated income level after mandatory retirement; they reported that not only did they desire but they also anticipated their income level to be some $60 \%$ to $70 \%$ of their current income level. In sum, the data presented in Table 3 reveal that nearly $80 \%$ of respondents anticipate that their income after mandatory retirement would drop at least to about $70 \%$ of their current income.

Table 4 presents a cross tabulation of desired minimum wage by anticipated wage in re-employment as a percentage of current annual wage. We have included bonus benefits into the wage. The results are 
Table 4. Desired minimum wage versus anticipated wage after age 60 (as a percentage of current income, male regular employees aged 57 to $59, \mathrm{~N}=1356$ ) (own calculations based on SCOLA 2007).

\begin{tabular}{|c|c|c|c|c|c|c|c|}
\hline \multirow{2}{*}{$\begin{array}{l}\text { Desired minimum } \\
\text { wage }\end{array}$} & \multicolumn{7}{|c|}{ Anticipated wage } \\
\hline & $\begin{array}{l}\text { More } \\
\text { than the } \\
\text { current } \\
\text { level }\end{array}$ & Same & $\begin{array}{l}80- \\
90 \%\end{array}$ & $\begin{array}{l}60- \\
70 \%\end{array}$ & $\begin{array}{l}40- \\
50 \%\end{array}$ & $\begin{array}{l}\text { Less } \\
\text { than } \\
30 \%\end{array}$ & Total \\
\hline $\begin{array}{l}\text { More than the } \\
\text { current level }\end{array}$ & 0.0 & 0.2 & 0.1 & 0.3 & 0.1 & 0.0 & 0.7 \\
\hline Same & 0.2 & 1.5 & 2.6 & 7.1 & 4.5 & 0.3 & 16.2 \\
\hline $80-90 \%$ & 0.0 & 1.8 & 3.0 & 14.1 & 6.6 & 1.3 & 26.9 \\
\hline $60-70 \%$ & 0.1 & 0.7 & 4.0 & 11.0 & 19.1 & 4.8 & 39.7 \\
\hline $40-50 \%$ & 0.0 & 0.1 & 0.7 & 4.8 & 4.5 & 4.5 & 14.6 \\
\hline Less than $30 \%$ & 0.0 & 0.1 & 0.0 & 0.4 & 0.7 & 0.7 & 1.9 \\
\hline Total & 0.3 & 4.6 & 10.3 & 37.6 & 35.5 & 11.6 & 100.0 \\
\hline
\end{tabular}

Table 5. Desired versus anticipated work status after age 60 (male regular employees aged 57 to 59, $\mathrm{N}=1356$ ) (own calculations based on SCOLA 2007).

\begin{tabular}{lcccccr}
\hline Desired work status & \multicolumn{7}{l}{ Anticipated work status } \\
\cline { 2 - 7 } & Regular & Contracted & Temporary & Dispatched & Other & Total \\
\hline Regular & 10.3 & 47.3 & 2.4 & 0.7 & 1.3 & 62.1 \\
Contracted & 0.4 & 29.0 & 1.0 & 0.5 & 0.4 & 31.4 \\
Temporary & 0.1 & 1.5 & 2.1 & 0.1 & 0.1 & 3.9 \\
Dispatched & 0.0 & 0.0 & 0.0 & 0.3 & 0.0 & 0.3 \\
Other & 0.0 & 1.4 & 0.1 & 0.1 & 0.7 & 2.3 \\
\hline Total & 10.8 & 79.2 & 5.7 & 1.8 & 2.6 & 100.0 \\
\hline
\end{tabular}

similar to those found in the data presented in Table 3 , and reveal some gaps between the desired minimum wage and the anticipated wage after mandatory retirement. For example, the largest (39.7\%) and the second largest $(26.9 \%)$ category of desired minimum wage level after mandatory retirement are $60 \%$ to $70 \%$ and $80 \%$ to $90 \%$ of current wages, respectively. However, the largest (37.6\%) and the second largest $(35.5 \%)$ category of anticipated income after mandatory retirement are $60 \%$ to $70 \%$ and $40 \%$ to $50 \%$ of current income, respectively.

In summary, about $80 \%$ of respondents expect their wages will fall to less than $70 \%$ of their current wage level and their anticipated wages after mandatory retirement is lower than the desired minimum wage.

Addressing the question of potential differences between the other desired and anticipated working conditions, Table 5 indicates discrepancies between desired and anticipated work status after age 60 . The 
Table 6. Desired versus anticipated work hours after age 60 (male regular employees aged 57 to 59, $\mathrm{N}=1356$ ) (own calculations based on SCOLA 2007).

\begin{tabular}{lrllllllr}
\hline Desired work hours & \multicolumn{9}{l}{ Anticipated work hours } \\
\cline { 2 - 10 } & $\begin{array}{l}\text { Full- } \\
\text { time }\end{array}$ & $\begin{array}{l}\text { Shorter } \\
\text { weekly } \\
\text { workdays }\end{array}$ & $\begin{array}{l}\text { Shorter } \\
\text { daily } \\
\text { work } \\
\text { hours }\end{array}$ & $\begin{array}{l}\text { Both } \\
\text { shorter time }\end{array}$ & $\begin{array}{l}\text { Fele- } \\
\text { work }\end{array}$ & Other & Total \\
& & & & & & & \\
\hline Full-time & 47.8 & 5.1 & 1.5 & 1.0 & 0.7 & 0.0 & 1.2 & 57.2 \\
Shorter weekly workdays & 10.9 & 6.6 & 0.3 & 0.6 & 0.3 & 0.0 & 0.3 & 19.0 \\
Shorter daily work hours & 3.5 & 0.7 & 2.1 & 0.2 & 0.1 & 0.0 & 0.2 & 6.9 \\
Both shorter & 3.2 & 0.7 & 0.4 & 2.4 & 0.1 & 0.0 & 0.4 & 7.1 \\
Flex-time & 4.4 & 1.3 & 0.1 & 0.4 & 1.5 & 0.0 & 0.3 & 8.0 \\
Tele-work & 0.1 & 0.1 & 0.0 & 0.0 & 0.0 & 0.1 & 0.0 & 0.4 \\
Other & 0.7 & 0.1 & 0.0 & 0.0 & 0.0 & 0.0 & 0.7 & 1.5 \\
\hline Total & 70.6 & 14.5 & 4.4 & 4.6 & 2.7 & 0.1 & 3.0 & 100.0 \\
\hline
\end{tabular}

largest category of desired work status after mandatory retirement is regular employment, preferred by about $62.1 \%$ of all respondents. On the other hand, the largest category of anticipated work status after mandatory retirement is contracted employment, reported by some $79.2 \%$. In contracted employment, the contract period is repetitively renewed (usually on an annual basis), and daily work hours or weekly work days are often shorter than those of regular employees. Almost half of all respondents $(47.3 \%)$ fall into the category of those who desire the work status of regular employment but anticipate the work status of contracted employment. Only $29.0 \%$ of respondents report a match in their desired and anticipated work status, which is contracted employment.

Table 6 indicates discrepancies between desired and anticipated work hours after mandatory retirement. At about $57.2 \%$, the largest category of desired work hours after age 60 is full time. The largest category of anticipated work hours after age 60 is also full time, as reported by $70.6 \%$ of respondents. About one in seven of these respondents $(10.9 \%)$ desire shorter weekly workdays. The proportion of respondents whose desired and anticipated work hours matched as full time is $47.8 \%$.

Table 7 shows a discrepancy between desired and anticipated workplace after age 60 . Around $80 \%$ of older workers desire to work in the same workplace as they are now working. However, one in eight of these respondents will not be able to match their desire to work in the same workplace, and they expect to work in a different establishment or in a different division of their current workplace.

Table 8 shows a discrepancy between desired and anticipated work content after age 60 . Around $80 \%$ of respondents desire to maintain 
Table 7. Desired versus anticipated workplace after age 60 (male regular employees aged 57 to 59, $\mathrm{N}=1356$ ) (own calculations based on SCOLA 2007).

\begin{tabular}{|c|c|c|c|c|c|c|}
\hline \multirow[t]{2}{*}{ Desired workplace } & \multicolumn{6}{|c|}{ Anticipated workplace } \\
\hline & $\begin{array}{l}\text { Same } \\
\text { establishment } \\
\text { and division }\end{array}$ & $\begin{array}{l}\text { Different } \\
\text { division }\end{array}$ & $\begin{array}{l}\text { Different } \\
\text { establishment }\end{array}$ & $\begin{array}{l}\text { Affiliate } \\
\text { companies }\end{array}$ & Other & Total \\
\hline $\begin{array}{l}\text { Same establishment } \\
\text { and division }\end{array}$ & 60.8 & 11.1 & 2.2 & 1.5 & 3.2 & 78.8 \\
\hline Different division & 4.5 & 5.2 & 0.7 & 0.4 & 0.2 & 10.9 \\
\hline $\begin{array}{l}\text { Different } \\
\text { establishment }\end{array}$ & 1.8 & 0.6 & 2.5 & 0.1 & 0.3 & 5,3 \\
\hline Affiliate companies & 0.7 & 0.1 & 0.2 & 0.9 & 0.1 & 2.0 \\
\hline Other & 1.1 & 0.2 & 0.2 & 0.0 & 1.4 & 2.9 \\
\hline Total & 69.0 & 17.2 & 5.8 & 2.9 & 5.2 & 100.0 \\
\hline
\end{tabular}

Table 8. Desired versus anticipated work contents after age 60 (male regular employees aged 57 to 59, $\mathrm{N}=1356$ ) (own calculations based on SCOLA 2007).

\begin{tabular}{lcccr}
\hline Desired job contents & \multicolumn{4}{l}{ Anticipated job contents } \\
\cline { 2 - 5 } & Same job & Different job & Other & Total \\
\hline Same job & 66.2 & 12.8 & 1.8 & 80.8 \\
Different job & 7.6 & 9.4 & 0.4 & 17.3 \\
Other & 0.9 & 0.1 & 0.8 & 1.8 \\
\hline Total & 74.7 & 22.3 & 3.0 & 100.0 \\
\hline
\end{tabular}

the same work content. However, about $12.8 \%$ of respondents will not be able to match their desire to keep the same work content, and they expect their job content to be different. On the other hand, some $9.4 \%$ of respondents desire different work content, and their anticipated work content is also different, as they wish.

To summarize the basic cross tabulations of desired and anticipated working conditions, most people want to keep the same work conditions even after their mandatory retirement age except a condition of work hours. More concretely, in re-employment, older workers want to maintain the same job contents $(80.8 \%)$ in the same firm and division $(78.8 \%)$ as regular $(62.1 \%)$ full-time $(57.2 \%)$ workers. However, discrepancies between desired and anticipated work conditions are found mainly in the following four distinguishable cases:

- Desired work status is regular employee, but anticipated work status is contracted employment ( $47.3 \%$ of the total).

- Desired daily working hours are the same, and weekly workdays are fewer than five days, but anticipated work hours are full time $(10.9 \%$ of the total). 
Table 9. Survey question responses - "What supports do you desire from your employers concerning their practices on continued work after age 60?" (male regular employees aged 57 to 59, $\mathrm{N}=1356$ ) (own calculations based on SCOLA 2007).

\begin{tabular}{|c|c|c|c|c|c|}
\hline & $\begin{array}{l}\text { Respond } \\
\text { for conti }\end{array}$ & $\begin{array}{l}\text { dents' des } \\
\text { inued em }\end{array}$ & $\begin{array}{l}\text { sired wor } \\
\text { iploymen }\end{array}$ & $\begin{array}{l}\text { k conditi } \\
\text { it }\end{array}$ & ions \\
\hline & $\begin{array}{l}\text { Desired } \\
\text { strongly }\end{array}$ & Desired & $\begin{array}{l}\text { Not } \\
\text { much } \\
\text { desired }\end{array}$ & $\begin{array}{l}\text { No } \\
\text { desired } \\
\text { at all }\end{array}$ & $\mathrm{N} / \mathrm{A}$ \\
\hline $\begin{array}{l}\text { Offering re-employment to whoever } \\
\text { wants to continue working }\end{array}$ & 25.0 & 56.4 & 14.7 & 2.3 & 1.6 \\
\hline $\begin{array}{l}\text { Relaxing qualifications for re-employment } \\
\text { opportunities }\end{array}$ & 16.1 & 55.5 & 22.4 & 3.2 & 3.0 \\
\hline $\begin{array}{l}\text { Further clarifying qualifications for re- } \\
\text { employment opportunities }\end{array}$ & 18.0 & 58.6 & 17.0 & 3.1 & 3.3 \\
\hline $\begin{array}{l}\text { Consideration of skills and know-how of } \\
\text { continued employees }\end{array}$ & 28.5 & 59.1 & 8.9 & 1.2 & 2.4 \\
\hline $\begin{array}{l}\text { Improving wage levels of re-employed } \\
\text { workers }\end{array}$ & 39.5 & 49.3 & 8.2 & 0.9 & 2.1 \\
\hline $\begin{array}{l}\text { Clarifying wage differences in re- } \\
\text { employment based on careers and job } \\
\text { contents }\end{array}$ & 11.6 & 40.1 & 40.3 & 5.4 & 2.6 \\
\hline Offering shorter work hours & 12.0 & 47.5 & 32.0 & 6.1 & 2.5 \\
\hline $\begin{array}{l}\text { Enhancing retirement preparation } \\
\text { programs and lifelong learning plan }\end{array}$ & 17.6 & 57.9 & 19.3 & 2.6 & 2.7 \\
\hline $\begin{array}{l}\text { Strengthening support for outplacement } \\
\text { and for self-employment start-ups }\end{array}$ & 9.5 & 30.9 & 45.3 & 11.4 & 3.0 \\
\hline
\end{tabular}

- Desired workplace is the same as where they are now working, but the anticipated workplace is different $(11.1 \%)$.

- Desired job content is the same as now, but anticipated work content is different $(12.8 \%$ of the total).

The SCOLA survey data provides more details of the respondents' needs with respect to work conditions in re-employment. Table 9 shows respondents' desired work conditions for continued employment after mandatory retirement. The degree of desirability is expressed on a scale of 1 to 4 ( 1 = desired strongly; $2=$ desired; $3=$ not much desired; $4=$ not desired at all). With respect to strongly desirable work conditions, about $39.5 \%$ of respondents desired "improved wage levels for re-employed workers (after age 60 )", and some $28.5 \%$ desired "consideration of skills and know-how of continued employees". With respect to work conditions not much desired, about $45.3 \%$ of respondents choose "strengthening supports for outplacement or for self-employment start-ups", and $40.3 \%$ of respondents chose "clarifying wage differences in re-employment based on careers and job contents". 
Table 10. Reasons why not to choose to be re-employed after age 60 (male regular employees aged 57 to 59, $\mathrm{N}=1356$ ) (own calculations based on SCOLA 2007).

\begin{tabular}{lr}
\hline Reasons why not to choose to be re-employed & \\
\hline I cannot work for desirable task & 29.5 \\
Our employers regard older workers as redundant staff & 20.8 \\
Atmosphere and human relationship are bad & 21.9 \\
The wage level is too low in re-employment & 41.5 \\
Mismatched working conditions in re-employment & 16.9 \\
Need to take over the family business & 4.9 \\
Switching job in other firms & 20.2 \\
Starting new business & 6.6 \\
Other reasons & 15.3 \\
\hline
\end{tabular}

The reasons why some older workers do not choose to be re-employed are shown in Table 10. Here, the respondents are restricted to those who do not want to be re-employed in the same firm after mandatory retirement. The largest proportion of the respondents (about $41.5 \%$ ) selected the reason, "the wage level is too low in re-employment". The second largest proportion (29.5\%) selected the reason, "I cannot work for a desirable task". Compared to the proportion of respondents who gave "the wage level is too low in re-employment" (41.5\%), the proportion of those who responded, "mismatched working conditions (work status, work hours, workplace) in re-employment" is low $(16.9 \%)$. To summarize, on the basis of these basic tabulations, it can be concluded that the dissatisfaction of wage levels in re-employment is stronger than other work conditions.

\section{Discussions}

The results of our multi-nomial logit model estimation are presented in Tables 11 and 12, showing marginal effects of each independent variable on dependent variables used in our analysis. Taking an example from Table 11, it can be evaluated that health problems increase the probability of retirement by $9.9 \%(=0.099)$ and decrease the probability of re-employment at the same firm by $11.1 \%(=-0.111)$. By definition, the sum of the three marginal effects indicated in the rows is equal to zero.

The sets of dependent and independent variables are almost the same in these two tables. The only difference is whether anticipated annual income or anticipated wages are used as part of the dependent variables. The variable of annual income consists of annual wages, bonus benefits, social security benefits, including both public pensions, 
Table 11. Multi-nomial logit analysis: The annual income model (own calculations based on SCOLA 2007).

\begin{tabular}{|c|c|c|c|c|c|c|}
\hline & $\begin{array}{l}\text { Retire } \\
\text { dy/xn }\end{array}$ & $\begin{array}{l}\text { ent } \\
{[S E]}\end{array}$ & $\begin{array}{l}\text { Re-em } 1 \\
\text { dy/xn }\end{array}$ & $\begin{array}{l}\text { loyment } \\
{[\mathrm{SE}]}\end{array}$ & $\begin{array}{l}\text { Job sec } \\
\text { dy/xn }\end{array}$ & $\begin{array}{l}\mathrm{rch} \\
{[\mathrm{SE}]}\end{array}$ \\
\hline With spouse & 0.002 & {$[0.025]$} & -0.015 & {$[0.038]$} & 0.012 & [0.029] \\
\hline With dependent children & -0.021 & {$[0.014]$} & 0.002 & {$[0.021]$} & 0.019 & {$[0.016]$} \\
\hline $\begin{array}{l}\text { With relatives needing } \\
\text { long-term care }\end{array}$ & 0.010 & {$[0.018]$} & -0.043 & {$[0.027]$} & 0.032 & {$[0.021]$} \\
\hline With health problem & 0.099 & {$[0.029]^{* * *}$} & -0.111 & {$[0.035]^{* * *}$} & 0.012 & [0.023] \\
\hline With home ownership & 0.003 & [0.024] & -0.002 & [0.036] & -0.001 & [0.027] \\
\hline Workplace located in Tokyo & -0.048 & {$[0.014]^{* * *}$} & 0.049 & {$[0.024]^{* *}$} & -0.001 & {$[0.020]$} \\
\hline Education: high school & -0.031 & {$[0.026]$} & 0.047 & {$[0.040]$} & -0.017 & [0.032] \\
\hline Education: two-year college & -0.006 & {$[0.035]$} & 0.038 & {$[0.048]$} & -0.032 & {$[0.033]$} \\
\hline Education: four-year college & -0.016 & {$[0.028]$} & 0.015 & {$[0.044]$} & 0.001 & [0.035] \\
\hline Length of service (years) & 0.001 & {$[0.001]$} & 0.001 & {$[0.001]$} & -0.002 & [0.001]* \\
\hline $\begin{array}{l}\text { Anticipated income fall: } \\
\text { by } 10-20 \%\end{array}$ & 0.019 & {$[0.036]$} & -0.148 & {$[0.085]^{*}$} & 0.129 & {$[0.087]$} \\
\hline $\begin{array}{l}\text { Anticipated income fall: } \\
\text { by } 30-40 \%\end{array}$ & -0.001 & {$[0.029]$} & -0.127 & {$[0.066]^{*}$} & 0.128 & {$[0.065]^{* *}$} \\
\hline $\begin{array}{l}\text { Anticipated income fall: } \\
\text { by } 50-60 \%\end{array}$ & -0.023 & [0.027] & -0.171 & {$[0.079]^{* *}$} & 0.194 & {$[0.080]^{* *}$} \\
\hline $\begin{array}{l}\text { Anticipated income fall: } \\
\text { by } 70 \% \text { and more }\end{array}$ & -0.006 & {$[0.036]$} & -0.350 & {$[0.125] * * *$} & 0.356 & {$[0.137]^{* * *}$} \\
\hline Main career: managerial & 0.038 & {$[0.034]$} & -0.018 & {$[0.041]$} & -0.020 & {$[0.025]$} \\
\hline Main career: professional & 0.003 & {$[0.037]$} & 0.058 & {$[0.044]$} & -0.061 & {$[0.023]^{* * *}$} \\
\hline Main career: clerical & 0.083 & {$[0.058]$} & -0.106 & {$[0.070]$} & 0.023 & [0.047] \\
\hline Main career: technical/skilled & 0.007 & {$[0.052]$} & -0.118 & {$[0.088]$} & 0.112 & {$[0.077]$} \\
\hline Main career: sales workers & 0.059 & {$[0.030]^{* *}$} & -0.051 & {$[0.036]$} & -0.008 & [0.023] \\
\hline Main career: logistic workers & 0.047 & [0.048] & -0.042 & {$[0.057]$} & -0.006 & [0.035] \\
\hline $\begin{array}{l}\text { Main career: researchers and } \\
\text { developers }\end{array}$ & 0.010 & {$[0.035]$} & -0.014 & {$[0.046]$} & 0.004 & [0.031] \\
\hline Main career: other & -0.006 & {$[0.025]$} & 0.022 & {$[0.035]$} & -0.016 & {$[0.025]$} \\
\hline Firm size: $300-499$ employees & 0.015 & {$[0.036]$} & 0.050 & {$[0.044]$} & -0.065 & {$[0.026]^{* *}$} \\
\hline Firm size: $500-999$ employees & -0.011 & {$[0.0$} & 0.099 & $2]^{* *}$ & -0.088 & {$[0.026]^{* * *}$} \\
\hline $\begin{array}{l}\text { Firm size: } 1000-2999 \\
\text { employees }\end{array}$ & 0.039 & {$[0.045]$} & 0.024 & {$[0.050]$} & -0.063 & {$[0.023]^{* * *}$} \\
\hline $\begin{array}{l}\text { Firm size: } 3000 \text { and more } \\
\text { employees }\end{array}$ & 0.023 & {$[0.050]$} & 0.043 & {$[0.054]$} & -0.067 & {$[0.021]^{* * *}$} \\
\hline Experience of job change & 0.011 & {$[0.018]$} & -0.040 & {$[0.028]$} & 0.029 & [0.021] \\
\hline $\begin{array}{l}\text { Experience of employment } \\
\text { transfer }\end{array}$ & 0.027 & {$[0.038]$} & 0.005 & {$[0.046]$} & -0.033 & [0.028] \\
\hline Work Status Type B & 0.008 & {$[0.02$} & 0.005 & {$[0.039]$} & -0.013 & [0.029] \\
\hline Work Status Type C & 0.067 & {$[0.036]^{*}$} & -0.051 & [0.044] & -0.016 & [0.028] \\
\hline Work Status Type D & 0.116 & {$[0.076]$} & -0.180 & {$[0.088]^{* *}$} & 0.064 & [0.059] \\
\hline Work Status Type E & 0.168 & {$[0.138]$} & -0.169 & {$[0.140]$} & 0.001 & {$[0.068]$} \\
\hline Work Hours Type B & 0.031 & {$[0.050$} & 0.019 & {$[0.056]$} & -0.049 & {$[0.026]^{*}$} \\
\hline Work Hours Type C & 0.043 & {$[0.046]$} & 0.007 & {$[0.051]$} & -0.050 & {$[0.024]^{* *}$} \\
\hline Work Hours Type D & 0.086 & {$[0.044]^{* *}$} & -0.101 & {$[0.050]^{* *}$} & 0.015 & [0.029] \\
\hline Work Hours Type E & -0.067 & {$[0.019]^{* * *}$} & 0.130 & {$[0.041]^{* * *}$} & -0.063 & {$[0.035]^{*}$} \\
\hline Workplace Type B & 0.007 & [0.053] & -0.062 & [0.091] & 0.055 & [0.081] \\
\hline Workplace Type C & -0.005 & {$[0.033]$} & -0.057 & {$[0.051]$} & 0.062 & [0.041] \\
\hline lace Type D & -0.009 & {$[0.030]$} & -0.122 & {$[0.053]^{* *}$} & 0.131 & {$[0.049]^{* * *}$} \\
\hline Workplace Type E & 0.011 & [0.043] & -0.208 & {$[0.080]^{* * *}$} & 0.197 & {$[0.077]^{* *}$} \\
\hline
\end{tabular}


Table 11. (continued)

\begin{tabular}{|c|c|c|c|c|c|c|}
\hline & \multicolumn{2}{|c|}{ Retirement } & \multicolumn{2}{|c|}{ Re-employment } & \multicolumn{2}{|c|}{ Job search } \\
\hline Job Contents Type B & 0.028 & {$[0.033]$} & -0.002 & {$[0.040]$} & -0.026 & {$[0.025]$} \\
\hline Job Contents Type C & 0.006 & {$[0.026]$} & -0.152 & {$[0.052] * * *$} & 0.146 & {$[0.048] * * *$} \\
\hline Job Contents Type D & 0.031 & {$[0.036]$} & -0.181 & {$[0.061]^{* * *}$} & 0.150 & {$[0.054] * * *$} \\
\hline Job Contents Type E & 0.032 & {$[0.060]$} & -0.133 & {$[0.092]$} & 0.102 & {$[0.079]$} \\
\hline $\begin{array}{l}\text { No corporation } \\
\text { pension right }\end{array}$ & -0.019 & [0.024] & -0.048 & {$[0.048]$} & 0.067 & {$[0.043]$} \\
\hline Pseudo $R^{2}$ & 0.1504 & & & & & \\
\hline Log likelihood & -809.89 & & & & & \\
\hline$N$ & 1356 & & & & & \\
\hline $\begin{array}{l}\text { Proportion of each } \\
\text { choice } \\
(n=1.00)\end{array}$ & 0.077 & & 0.825 & & 0.098 & \\
\hline
\end{tabular}

Note: $* * *$ indicates statistical significance level at $1 \%, * *$ at $5 \%$, and $*$ at $10 \%$.

and respondents' salary supplements. The variable of wages includes base pay and bonus benefits.

The dependent variable corresponds to three choices: (i) re-employment in the same firm, (ii) retirement, and (iii) job search. We would expect that the survey respondents are more sensitive to anticipated annual income than to anticipated wages in making their decision among these three choices. This is because the literature on this subject indicates older people's labor market decisions are also influenced by the level of social security benefits, as the benefits have earnings-test rules (e.g., Ogawa 1998; Seike 1993; Seike and Yamada 2004). From the perspective of older workers, arguably, income reflects the ability to cover the costs of living, whereas wage also reflects the value placed on one's continued work. In this context, therefore, we examined wage as a separate variable from income. By distinguishing between these two variables, the aim was to disentangle two potentially distinct motivations underlying the respondents' labor market decisions.

The base category includes: without spouse, no dependent family members, no family members who need long-term care, subjective health status is good, no home ownership, workplace is not Tokyo, education level is junior high school (the lowest), anticipated annual income after age 60 is the same as current level, major career field is manufacturing, firm size is fewer than 300 employees (the smallest), no experience of job change and/or employment transfer, Work Status Type A (i.e., regular employment is desired, and regular employment is also anticipated), Work Hours Type A (i.e., full-time work is desired, and full-time work is also anticipated), Workplace Type A (i.e., the same workplace where employee is now working is desired, and the 
same workplace is also anticipated), Job Contents Type A (i.e., the same job content as is currently done is desired and the same job content is also anticipated, and with corporate pension rights).

In order to find out whether or not the large drop in income or wages after mandatory retirement (age 60) induces retirement, the anticipated annual income was used as an independent variable. But, as shown in Table 11, there is no evidence to suggest such an induction of retirement. The result suggests that a $50 \%$ to $60 \%$ income drop decreases probability of re-employment at the same firm by about $17.1 \%$. Simultaneously, the income drop increases probability of job search (for employment in other firms) by $19.4 \%$. Additionally, even if the income drop is larger (more than $70 \%$ ), the probability of job search increases by $35.6 \%$, and the respondents still reported that they wanted to work outside of the current firms.

In order to find out whether or not discrepancies between desired and anticipated work conditions affect a decision of continued employment adversely, the analysis considered four areas of work conditions: work status, work hours, workplace, and work contents. The discrepancies do have some influence on the respondents' labor market decisions. For work status, the analysis revealed that, if the respondents desired nonregular employment but the anticipated type of nonregular employment is mismatched (Work Status Type D), the probability of their re-employment at the same firm decreases by $18 \%$. For work hours, the analysis revealed that, if the respondents desired shorter work hours than full time but the anticipated work hour type is mismatched (Work Hours Type D), their probability of re-employment at the same firm decreases by about $10.1 \%$. In this case, their probability of retirement also increases by about $8.6 \%$.

Concerning discrepancies of workplace and job contents, the results are somewhat predictable. If the respondents desired different workplaces but anticipated the same establishment or the same division (Workplace Type D), their probability of re-employment at the same firm decreases by some $12.2 \%$ and their probability of conducting a job search (for employment at other firms) increases by about $13.1 \%$. If the respondents desired a different job but anticipated the same job (Job Contents Type D), their probability of re-employment at the same firm decreases by about $18.1 \%$ and their probability of conducting a job search increases by some $15.0 \%$. Interestingly, if the respondents desired a different job and a different job is anticipated (Job Contents Type C), the probability of both re-employment at the same firm and job search at other firms changes in the same direction as for Job Contents Type D; the probability of re-employment at the same firm decreases by about $15.2 \%$, and the probability of conducting a job search 
Table 12. Multi-nomial logit analysis: The annual wage model (own calculations based on SCOLA 2007).

\begin{tabular}{|c|c|c|c|c|c|c|}
\hline & \multicolumn{2}{|c|}{ Retirement } & \multicolumn{2}{|c|}{ Re-employment } & \multicolumn{2}{|c|}{ Job search } \\
\hline With spouse & 0.003 & {$[0.025]$} & -0.012 & {$[0.038]$} & 0.009 & {$[0.030]$} \\
\hline With dependent children & -0.019 & {$[0.014]$} & 0.001 & {$[0.022]$} & 0.018 & {$[0.017]$} \\
\hline $\begin{array}{l}\text { With relatives needing } \\
\text { long-term care }\end{array}$ & 0.010 & {$[0.018]$} & -0.042 & {$[0.027]$} & 0.032 & {$[0.021]$} \\
\hline With health problem & 0.100 & {$[0.029]^{* * *}$} & -0.109 & {$[0.035]^{* * *}$} & 0.009 & [0.023] \\
\hline With home ownership & 0.004 & {$[0.023]$} & -0.003 & {$[0.035]$} & -0.001 & {$[0.027]$} \\
\hline Workplace located in Tokyo & -0.050 & {$[0.014]^{* * *}$} & 0.052 & {$[0.024]^{* *}$} & -0.002 & {$[0.020]$} \\
\hline Education: high school & -0.033 & {$[0.026]$} & 0.048 & {$[0.040]$} & -0.015 & [0.032] \\
\hline Education: two-year college & -0.007 & {$[0.034]$} & 0.032 & {$[0.049]$} & -0.025 & {$[0.036]$} \\
\hline Education: four-year college & -0.018 & {$[0.027]$} & 0.010 & {$[0.044]$} & 0.008 & {$[0.035]$} \\
\hline Length of service (years) & 0.001 & {$[0.001]$} & 0.001 & {$[0.001]$} & -0.001 & {$[0.001]$} \\
\hline $\begin{array}{l}\text { Anticipated wage fall: } \\
\text { by } 10-20 \%\end{array}$ & -0.033 & {$[0.027]$} & -0.069 & {$[0.102]$} & 0.102 & {$[0.103]$} \\
\hline $\begin{array}{l}\text { Anticipated wage fall: } \\
\text { by } 30-40 \%\end{array}$ & -0.015 & {$[0.033]$} & -0.080 & {$[0.075]$} & 0.096 & {$[0.072]$} \\
\hline $\begin{array}{l}\text { Anticipated wage fall: } \\
\text { by } 50-60 \%\end{array}$ & -0.044 & {$[0.031]$} & -0.123 & {$[0.086]$} & 0.167 & {$[0.085]^{* *}$} \\
\hline $\begin{array}{l}\text { Anticipated wage fall: } \\
\text { by } 70 \% \text { and More }\end{array}$ & -0.016 & {$[0.034]$} & -0.233 & {$[0.131]^{*}$} & 0.249 & {$[0.137]^{*}$} \\
\hline Main career: managerial & 0.045 & {$[0.035]$} & -0.018 & {$[0.041]$} & -0.028 & {$[0.024]$} \\
\hline Main career: professional & 0.004 & {$[0.037]$} & 0.061 & {$[0.043]$} & -0.065 & {$[0.022]^{* * *}$} \\
\hline Main career: clerical & 0.086 & {$[0.058]$} & -0.105 & {$[0.070]$} & 0.020 & {$[0.046]$} \\
\hline Main career: technical/skilled & 0.010 & {$[0.053]$} & -0.115 & {$[0.087]$} & 0.105 & {$[0.074]$} \\
\hline Main career: sales workers & 0.059 & {$[0.030]^{* *}$} & -0.047 & {$[0.036]$} & -0.013 & {$[0.022]$} \\
\hline Main career: logistic workers & 0.052 & {$[0.049]$} & -0.040 & {$[0.057]$} & -0.013 & {$[0.034]$} \\
\hline $\begin{array}{l}\text { Main career: researchers and } \\
\text { developers }\end{array}$ & 0.012 & {$[0.035]$} & -0.014 & {$[0.0$} & 0.002 & {$[0.032]$} \\
\hline Main career: other & -0.005 & {$[0.025]$} & 0.023 & {$[0.035]$} & -0.017 & {$[0.025]$} \\
\hline Firm size: $300-499$ employees & 0.016 & {$[0.036]$} & 0.048 & {$[0.045]$} & -0.064 & {$[0.027]^{* *}$} \\
\hline Firm size: $500-999 \mathrm{em}$ & -0.010 & {$[0.033]$} & 97 & {$[0.0$} & -0.087 & {$[0.026]^{* * *}$} \\
\hline $\begin{array}{l}\text { Firm size: } 1000-2999 \\
\text { employees }\end{array}$ & 0.040 & {$[0.045]$} & 0.021 & {$[0.051]$} & -0.060 & {$[0.024]^{* *}$} \\
\hline $\begin{array}{l}\text { Firm size: } 3000 \text { and more } \\
\text { employees }\end{array}$ & 0.020 & {$[0.049]$} & 0.049 & {$[0.053]$} & -0.068 & {$[0.021]^{* * *}$} \\
\hline Experience of job change & 0.012 & {$[0.018]$} & -0.043 & {$[0.028]$} & 0.032 & {$[0.022]$} \\
\hline $\begin{array}{l}\text { Experience of employment } \\
\text { transfer }\end{array}$ & 0.029 & {$[0.038]$} & -0.001 & {$[0.047]$} & -0.028 & {$[0.029]$} \\
\hline Work Status Type B & 0.010 & {$[0.028]$} & 6 & {$[0.039]$} & -0.017 & {$[0.029]$} \\
\hline Work Status Type C & 0.069 & {$[0.036]^{*}$} & -0.048 & {$[0.044]$} & -0.020 & {$[0.028]$} \\
\hline Work Status Type D & 0.125 & {$[0.080]$} & -0.193 & {$[0.090] * *$} & 0.067 & {$[0.060]$} \\
\hline Work Status Type E & 0.199 & {$[0.149]$} & -0.188 & {$[0.147]$} & -0.012 & {$[0.062]$} \\
\hline Work Hours Type B & 0.029 & {$[0.049]$} & 0.026 & {$[0.054]$} & -0.055 & {$[0.025]^{* *}$} \\
\hline Work Hours Type C & 0.040 & & & & -0.050 & {$[0.025] * *$} \\
\hline Work Hours Type D & 0.086 & {$[0.044]^{* *}$} & -0.101 & {$[0.050] * *$} & 0.015 & {$[0.030]$} \\
\hline Work Hours Type E & -0.069 & {$[0.016] * * *$} & 0.140 & {$[0.036]^{* * *}$} & -0.070 & {$[0.031]^{* *}$} \\
\hline Workplace Type B & 0.001 & {$[0.049]$} & -0.066 & {$[0.094]$} & 0.065 & {$[0.087]$} \\
\hline Workplace Type C & -0.007 & {$[0.033]$} & -0.057 & {$[0.051]$} & 0.064 & {$[0.042]$} \\
\hline Workplace Type D & -0.011 & [0.029] & -0.121 & {$[0.053]^{* *}$} & 0.131 & {$[0.049] *$} \\
\hline Workplace Type E & 0.007 & {$[0.041]$} & -0.201 & {$[0.079]^{* *}$} & 0.194 & {$[0.076]^{* *}$} \\
\hline
\end{tabular}


Table 12. (continued)

\begin{tabular}{|c|c|c|c|c|c|c|}
\hline & \multicolumn{2}{|c|}{ Retirement } & \multicolumn{2}{|c|}{ Re-employment } & \multicolumn{2}{|c|}{ Job search } \\
\hline & $\mathrm{dy} / \mathrm{xn}$ & [SE] & $\mathrm{dy} / \mathrm{xn}$ & {$[\mathrm{SE}]$} & $\mathrm{dy} / \mathrm{xn}$ & [SE] \\
\hline Job Contents Type B & 0.028 & {$[0.032]$} & -0.004 & [0.040] & -0.025 & {$[0.025]$} \\
\hline Job Contents Type C & 0.002 & {$[0.025]$} & -0.160 & {$[0.053] * * *$} & 0.158 & {$[0.050] * * *$} \\
\hline Job Contents Type D & 0.024 & {$[0.033]$} & -0.192 & {$[0.061] * * *$} & 0.168 & {$[0.056]^{* * *}$} \\
\hline Job Contents Type E & 0.037 & {$[0.062]$} & -0.161 & {$[0.096]^{*}$} & 0.123 & [0.086] \\
\hline $\begin{array}{l}\text { No corporation } \\
\text { pension right }\end{array}$ & -0.013 & {$[0.026]$} & -0.049 & {$[0.048]$} & 0.062 & {$[0.042]$} \\
\hline Pseudo $R^{2}$ & 0.1511 & & & & & \\
\hline Log likelihood & -809.31 & & & & & \\
\hline$N$ & 1356 & & & & & \\
\hline $\begin{array}{l}\text { Proportion of each } \\
\text { choice }(n=1.00)\end{array}$ & 0.077 & & 0.825 & & 0.098 & \\
\hline
\end{tabular}

Note: $* * *$ indicates statistical significance level at $1 \%, * *$ at $5 \%$, and $*$ at $10 \%$.

increases by some $14.6 \%$. A possible explanation for this outcome is that the respondents categorized in Job Content Type $\mathrm{C}$ may have more general skills, which can be also utilized in other firms.

Table 12 presents the wage model, based on the dependent variable of anticipated wage drops instead of anticipated annual income falls. This model suggests very similar results to those presented in Table 11. Focusing on the variable of anticipated wage drops revealed that an anticipated large wage drop increases the probability of job search rather than the probability of retirement. A $50 \%$ to $60 \%$ wage drop increases the probability of conducting a job search by about $16.7 \%$. Furthermore, even if the wage drop is larger than $70 \%$, the probability of job search increases by some $24.9 \%$, and the respondents still preferred to look for employment opportunities outside of their current firms rather than choosing retirement. However, the statistical significance of wage drop is weaker than that of annual income fall. The possible explanation for this observation that the respondents react more sensitively to annual income decline than to wage drops is that annual income is a better indicator of the respondents' economic wellbeing than wage.

To summarize the results presented in Tables 11 and 12, work conditions, such as work status, work hours, workplace, and job contents, affect the respondents' decision of re-employment as much as annual income. Those who desire nonregular, non-full-time work at a different workplace, and with different job contents, but anticipate mismatched work conditions, do not want to be re-employed at the same firm but would seek employment opportunities outside of their current firms. From the viewpoint of social policymakers, the discrepancies between 
desired non-full-time work and mismatched anticipated work hours could be problematic as it induces retirement and opposes their policy objective of keeping older workers in the labor force longer.

\section{Conclusion}

In this paper, we have examined three specific questions related to older workers' views of their future labor market prospects under the current institutional arrangements of the labor market in contemporary Japan. Under the current institutional arrangements, when choosing to be re-employed by the same employers, older workers are likely to undergo large wage reductions after mandatory retirement.

This paper has presented data drawn from a nationally representative sample of 1,400 male regular employees aged 57 to 59 - those who are approaching age 60, the typical mandatory retirement age in Japan. First, we examined whether the institutionally arranged large wage reduction discourages older workers from choosing to be re-employed by the same employers after mandatory retirement. Second, we examined what labor market behaviors older workers would exhibit if they chose not to be re-employed. Finally, we explored the other institutional factors in the current Japanese labor market, besides the large wage reduction, that may discourage older workers from choosing to be re-employed by their employers. Analysis of the data was based on a series of basic cross tabulations and suggests the following five tendencies:

1. For the majority of the sample (about $80 \%$ ), anticipated levels of wage or income in re-employment are equivalent to around $60 \%$ to $70 \%$ of their current wages or income levels. These anticipated wages in re-employment are lower than the desired wages for most respondents.

2. One out of ten respondents anticipates an income drop in re-employment of more than $70 \%$ of their current income. This suggests that some older workers are likely to face the risk of poverty during the period between the ages of mandatory retirement and pension eligibility.

3. Desired working conditions are more or less similar to those of current working conditions. About $60 \%$ of respondents desire regular full-time employment, and around $80 \%$ desire to work in the same workplaces doing the same job contents.

4. Discrepancies between desired and anticipated working conditions in re-employment at the same firm are found mainly in four categories (the percentage of older workers aged 57 to 59 whose situation 
fits each category is shown in parentheses). These categories are (a) the desired work status is regular employee but anticipated work status is contracted employee $(47.3 \%)$; (b) the desired work hours are shorter than full time but anticipated work hours are full time $(10.9 \%)$; (c) the desired workplace is the same as the current one but anticipated workplace is different $(11.1 \%)$; and (d) the desired job contents are the same as those currently done but anticipated job contents are different $(12.8 \%)$.

5. The complaint about the low wage or income in re-employment at the same firm is more pronounced than complaints about other work conditions.

On the basis of an estimation of the multi-nomial logit model of older workers' decisions about re-employment, we found the following four tendencies:

1. Older workers do not want to be re-employed in the same firms when their prospective wages or incomes are substantially lower. This is the case even though the unemployment rate is quite high among older workers; the rate among those aged 60 to 64 was $6.3 \%$ in 2009 , that is, $1.2 \%$ higher than the total population average (Statistics Bureau 2010).

2. When they do not want to be re-employed in the same firms, older workers prefer employment opportunities outside their firms, rather than retiring with a public pension.

3. Prospective wage levels in re-employment in the same firms is not the only factor affecting older workers' decisions about future labor market behaviors. Total prospective income, which includes "inwork" social security benefits, is even more crucial. This finding suggests that such social security benefits act as wage subsidies, which may induce further wage reductions among re-employed older workers.

4. Flexible work options are another important factor affecting older workers' decisions; older workers who desire to work as non-fulltime workers but whose anticipated work hours are not matched are likely to decide to completely retire from the labor force.

On the basis of these findings, we argue that the large wage or income drop in re-employment induces older worker to leave the firms where they are currently working after mandatory retirement. The older workers who intend to leave their firms usually desire to be re-employed by other firms.

In this regard, the large wage drop is unlikely to reduce the total labor force participation rate of older people, although it obviously 
reduces the rate of re-employment in the same firms. However, there is no guarantee of other employment, and some job seekers may be trapped in unemployment as a result of declining re-employment at the same firms. Some of them may have to accept a large reduction in wage or income at the same firms because of the risk of unemployment.

From the perspective of policymakers, to date, the LSEOP seems to have been effective in promoting labor force participation among older workers aged 60 to 64. In 2005, one year prior to the introduction of the LSEOP, the employment rate of males aged 60 to 64 was about $65.9 \%$. Along with the effect of the upward revision of pensionable age, the employment rate of this particular age group has in effect increased to some $71.4 \%$ by 2009 (Statistics Bureau 2010).

However, the increase in the labor participation rate among older people to date is still lower than the level expected by policymakers; the latest actuarial review of Employees' Pension is based on an expected scenario for the increased labor participation of males aged 60 to 64. In this scenario, the labor participation rate among this particular population is expected to increase to about $81.3 \%$ by 2020 (JILPT 2008). This expected figure is nearly $10 \%$ higher than the actual rate observed in 2009. In the long run, the current labor force participation rate among this population is still not high enough to promise the sustainability of the Employees' Pension system.

Furthermore, despite amendments made to the LSEOP, it is clear that there still is a problem of income insecurity among older workers. Under the current institutional contexts in Japan, employers hold a considerable degree of discretion in reducing the wage levels of their re-employed workers. As our analysis clearly suggests, large wage drops are more likely to induce older workers who are approaching mandatory retirement age to leave their firms. This tendency goes against the fundamental goal of the LSEOP, which aims to strengthen employment security of older workers, particularly during the period between mandatory retirement and pensionable age. Using employer survey data, Yamada (2007) has already addressed this issue as a policy problem. The analysis presented in this paper confirms this.

We argue that the large drop in wage or income that older workers tend to experience in re-employment calls for policymakers' attention to issues about appropriate income security for those older workers who need - and are willing - to work beyond the conventional retirement age. However, policy interventions aiming to prohibit the current wage drop may not be a sound option; the high labor force participation rate among older workers in Japan today may be best explained by the aforementioned discretion given to employers in reducing the wages of older workers who have reached mandatory retirement age 
(Yamada 2010). ${ }^{6}$ Restricting employers' flexibility in reducing wages is likely to yield adverse effects on the employment rates among older workers. Considering such limitations in labor policy interventions, we suggest that policymakers consider developing measures for a social security safety net for the unemployed.

By 2013, the challenges that policymakers in Japan will face are likely to be even more serious. This is because in 2013 the pensionable age of the earnings-related portion of the Employees Pension is scheduled to rise. The most crucial implication of this change is that there will be no income for a substantial number of older persons aged 61 unless they remain in the paid labor force. Therefore, policymakers in Japan should carefully examine and assess possible poverty risks among those future older workers who choose - or have no chance - to be reemployed by their employers. Future research needs to investigate fully older workers' desirable work hours in re-employment as it is the only work condition that tends to induce older workers to retire from the labor force.

In the midst of growing global concern about aging populations and workforces, Japan stands as a unique case. Having already experienced the world's fastest population aging over the past few decades, Japan anticipates a much more severe workforce shortage in coming decades compared to many other industrialized countries. However, policymakers in Japan have few models to follow in order to deal with these policy challenges. Rather, other industrial countries with aging workforces will closely examine the Japanese case. Present and future Japanese experiences may yield significant lessons for those aging countries that anticipate similar labor force and policy challenges as to how to mitigate institutional barriers to current and future older workers' continued labor force participation beyond conventional retirement age.

Atsuhiro Yamada (atsuhiro@econ.keio.ac.jp) is Associate Professor of Social Policy at Keio University. He is one of the authors of The Economics of Older Workers in Japan (in Japanese, 2004). He has written on the effects of various public policies related to older workers and, as a national expert for the OECD, conducts research on income distribution among older people in Japan from an international comparative perspective.

Masa Higo (higo@bc.edu) is Research Associate at the Sloan Center on Aging \& Work at Boston College. He also teaches sociology at Boston College, Lasell College, and Montserrat College of Arts, and has conducted research with international perspective. His research fo- 
cuses mainly upon the impact of global aging and economic globalization on socioeconomic well-being, employment institutions, and social justice across regions of the world.

\section{Notes}

1. Nevertheless, in Japan, the amendment of the Employment Measures Act in 2001 obliged all employers to make efforts to abolish upper age limits for hiring. Arguably, this was the first attempt of the country's employment-related policy to set out some sort of anti-age discrimination rule.

2. See Seike and Yamada (2004) for more detailed discussions concerning the past research on the impact of the earnings-test components of the current pension scheme in Japan on working pensioners.

3. See Casey $(2001,2004)$ for a more comprehensive discussion of Japanese retirement income systems from a cross-national comparative perspective.

4. The Japanese public pension scheme has been designed to be reformed every five years based mainly on actuarial reviews and assessments (Cabinet Office 2008).

5. The Survey was conducted in 2007, but the report based on the data was published by JILPT in 2008. In this paper we refer to the survey as SCOLA 2007, rather than JILPT 2007.

6. Yamada's (2010) analysis of time-series data suggests that when older workers' wages are relatively lower than those of younger workers, employment rates among older workers have increased.

\section{References}

Blöndel, Sveinbjörn \& Stefano Scarpetta 1998. The retirement decision in OECD countries (OECD Economics Department, working paper no. 202). Paris: OECD.

Cabinet Office. 2008. White paper on the aging society. Tokyo: Office of Government Public Relations.

Cabinet Office. 2010. Annual report on the aging society: 2009. Tokyo: Office of Government Public Relations.

Casey, Bernard. 2001. The employment of older people: Can we learn from Japan? Paris: Centre d'études prospectives et d'informations internationales (CEPII). http://www.cepii.fr/anglaisgraph/communications/pdf/2001/enepri07080901/ casey.pdf (accessed 17 November 2007).

Casey, Bernard. 2004. Reforming the Japanese retirement income system: A special case? A Series of Global Briefs 4 (September). Boston: Center for Retirement Research at Boston College. http://crr.bc.edu/images/stories/Briefs/gib_4.pdf (last accessed 25 October 2010).

Duval, Romani. 2003. The retirement effects of old-age pension systems and other social transfer programmes in OECD countries (OECD Economics Department, working paper no. 370). Paris: OECD.

Gruber, Jonathan \& David Wise (eds.). 1999. Social security and retirement around the world. Chicago: University of Chicago Press.

Gruber, Jonathan \& David Wise (eds.). 2004. Social security programs and retirement around the world: Micro-estimation. Chicago: University of Chicago Press.

Higo, Masa \& Atsuhiro Yamada. 2009. Japan: Public policy. Global Policy Brief No 2 (July 2009). Boston: The Sloan Center on Aging \& Work at Boston College. 
http://www.bc.edu/research/agingandwork/meta-elements/pdf/publications/ GPB02_Japan.pdf (accessed 25 October 2010).

Hurd, Michael. 1990. The joint retirement decisions of husbands and wives. In David Wise (ed.), Issues in the economics of aging, 231-258. Chicago: University of Chicago Press.

JILPT (Japan Institute for Labor Policy and Training). 2007. Kōnenreisha no keizoku kōyō no jittai ni kansuru chōsa [Report on the actual situation of older people's re-employment]. http://www.jil.go.jp/press/documents/20070402.pdf (accessed 14 June 2010).

JILPT (Japan Institute for Labor Policy and Training). 2008. Rōdō-ryoku-jyukyū no suikei; Rōdō-ryoku-jyukyū moderu (2007-nenban) niyoru shōrai suikei [Projection of the balance of labor supply and demand; Projection based on the 2007 model for the balance of labor supply and demand]. http://www.jil.go.jp/institute/ chosa/2008/08-034.htm (accessed 14 March 2010).

JILPT (Japan Institute for Labor Policy and Training). 2009. Labor situation in Japan and analysis 2008/2009. Tokyo: Japan Institute for Labor Policy and Training \& Daitō Press.

Lazear, Edward. 1979. Why is there mandatory retirement? Journal of Political Economy 87 (6). 1261-1284.

Lazear, Edward. 1986. Retirement from the labor force. In Orley Ashenfelter \& Richard Layard (eds.), Handbook of labor economics I, 305-355, Amsterdam: North-Holland.

MHLW (Ministry of Health, Labor, and Welfare). 2006. Kōnenreisha shūgyō jittai chōsa [Survey on employment conditions of elderly persons]. Tokyo: MHLW.

MHLW (Ministry of Health, Labor, and Welfare). 2009. Heisei 21-nen shürō jōken sōgō chōsa kekka [Comprehensive survey on work conditions]. http:// www.mhlw.go.jp/toukei/itiran/roudou/jikan/syurou/09/index.html (accessed 29 August 2010).

Munnell, Alicia \& Steven Sass. 2008. Working longer: The solution to the retirement income challenge. Washington, DC: Brookings Institution Press.

OECD (Organization for Economic Co-operation and Development). 2004. Ageing and employment policies: Japan. Paris: OECD.

OECD (Organization for Economic Co-operation and Development). 2006. Live longer, work longer. Paris: OECD.

Ogawa, Hiroshi. 1998. Nenkin koyō hoken kaikaku to dansei kōreisha no shūgyō kōdō no henka [Reforms of public pension and unemployment insurance and changes of labor supply decision of older male workers]. The Japanese Journal of Labour Studies 461. 52-64.

Ono, Hiroshi. 2007. Lifetime employment in Japan: Concepts and measurements. Journal of the Japanese and International Economies 24 (1). 1-27.

Schils, Trudie. 2005. Early retirement patterns in Europe: A comparative panel study. Amsterdam: Dutch University.

Schulz, James H. \& Robert H. Binstock. 2008. Aging nation: The economics and politics of growing older in America. Baltimore, MD: Johns Hopkins University Press.

Seike, Atsushi. 1993. Kōreika shakai no rōdō shijyō; shūgyō kōdō to kōteki nenkin [Labor market in an aging society; work and pension]. Tokyo: Tōyō Keizai Shinpōsha.

Seike, Atsushi \& Atsuhiro Yamada. 2004. Kōreisha shūgyō no keizaigaku [The economics of older workers]. Tokyo: Nihon Keizai Shinbunsha.

Statistics Bureau. 2010. Labour force survey; Historical data. http://www.stat.go.jp/ english/data/roudou/lngindex.htm (accessed 29 August 2010). 
Yamada, Atsuhiro. 2007. The effectiveness of new job security measure for the older employees in Japan. Japan Institute for Labor Policy and Training (ed.), Köreisha keizoku koyō ni muketa jinji rōmu kanri no genjō to kadai [Report on current conditions and challenges for human resource management of continued employment of older people] (Rōdō seisaku kenkyū hōkokusho [Labour policy research series] 83). Tokyo: JILPT. http://www.jil.go.jp/institute/reports/2007/ 083.htm (accessed 14 March 2010).

Yamada, Atsuhiro. 2010. Labor force participation rates of older workers in Japan: Impacts of retirement policy, steep age-wage profile, and unionization. The Japanese Economy 37 (1). 3-39. 